\title{
BUSINESS ETHICS IN INSURANCE INDUSTRY IN NIGERIA
}

\author{
Isimoya $\mathbf{O} .^{1}$ \\ 'Department of Actuarial Science and Insurance University of Lagos, Akoka, Lagos
}

\begin{abstract}
This study conceptually $x$-rayed the insurance practice in Nigeria, particularly the non-adherence to business ethics philosophy in their operations. Though Nigeria potentially has the largest insurance market in the African continent, she trails behind South Africa, Egypt, and Morocco in insurance market premium volume in 2011. This study revealed that unethical practices holds sway in the industry, resulting in lost of confidence, poor insurance patronage and stunted growth for insurance industry. Drawing from the theoretical perspectives of business ethics, we recommend the adoption of business ethical relationship philosophy by Nigeria insurance industry, if she is to be liberated from her current economic doldrums.
\end{abstract}

Keywords: Business ethics, Nigeria insurance industry, Investment unethical practices, Ethical theories.

Received: 29 January 2014/ Revised: 27 February 2014/ Accepted: 1 April 2014/ Published: 14 April 2014

\section{INTRODUCTION}

Since the dawn of $21^{\text {st }}$ century, Nigerian insurance industry, have been in doldrums the number of insurance companies operating was reduced from 104 under-capitalized underwriting firms to only 51 successfully recapitalized firm by September, 2007. The reduction of the number of operating firms was the outcome of government pronouncement that all insurance firms should be recapitalized. The recapitalization exercise increased the statutorily required capital for life insurance business from $\$$ 150million to $\$$ 2billion, general insurance business from $\$ 200$ million to \$3billion and reinsurance from \$350million to $\$ 1$ 10billion.Obaremi (2007) stated that potentially, Nigeria has the biggest insurance market in Africa, but weaknesses in the industry meant that most of the large insurance business was underwritten by foreign companies. In addition, now the domestic industry is poised not only to penetrate deeper in the domestic market, but to expand to other regions of the continent.

The aim of the recapitalization was to improve performance. 
For instance, underwriting firms venturing into the hitherto considered high profile risks like, aviation; oil and gas; large industrial fire risks, etc. instead of ceding all the risks to more capital and technically competent firms abroad. Second, with the new capital at their disposal, it was the expectations of all stakeholders in the insurance industry; that insurance management would have enough funds to carry out research, market development and repositioning their firms for better image and reputation to attract more patronage.

Six years after recapitalization exercise is enough time to assess the performance off the industry, whether it is in line with the expectations of the stakeholders. However, Ibrahim and Abubakar (2011), in a study titled "Recapitalization and Profitability of Quoted Insurance Companies in Nigeria, reported thus, "The findings from the study revealed that recapitalization has not impacted significantly on the profitability of quoted insurance companies in Nigeria both before and after the 2006 recapitalization, even though there are some indications for improvement in absolute average profit figures during the post recapitalization, the increase in the share capital base of insurance companies Nigeria, does not commensurate with the level of profitability achieved by the companies". Additionally, Insurance Professionalism in Nigeria (2011), statistically showed Nigerian Insurance Industry as being in the fourth position among the top 10 African countries total premium volume for 2011. Nigeria trials behind South Africa, Morocco and Egypt, even though she potentially has the largest insurance market population in African continent. Azmi (2006) stated that Ethics is an attempt to work out the rights and obligations we have and share with others. This implies according to (Azmi, 2006) that business ethics becomes a prerequisite for conducting any type of business, particularly in the global market place. No business organization operates in a vacuum, but rather have multiple relationship with stakeholders such as customers, employees, suppliers, etc. who perhaps would prefer their company to be ethical. Azmi (2006) also noted that the importance of building a strong ethical culture is integral to the reputation, growth, and finances of any organization. It builds a brand that attracts the best talent and creates trust among the stakeholders. Furthermore, he sends business competitiveness, when ethical failure diminishes the reputation of a company and its products, locally and globally.

The table 1 below shows Nigeria's position in comparison with other African countries.

Table-1. Total Premium Volume in some Selected African Countries 2011

\begin{tabular}{cccc}
\hline Ranking & Country & Premium Volume (Million USD) & Share of World Market 2011 (\%) \\
\hline 1 & South Africa & 52,371 & 1.14 \\
\hline 2 & Morocco & 2859 & 0.06 \\
\hline 3 & Egypt & 1714 & 0.04 \\
\hline 4 & Nigeria & 1557 & 0.03 \\
\hline 5 & Algeria & 1201 & 0.03 \\
\hline 6 & Kenya & 1036 & 0.02 \\
\hline 7 & Angola & 1000 & 0.02 \\
\hline 8 & Namibia & 971 & 0.02 \\
\hline 9 & Tunisia & 812 & 0.02 \\
\hline 10 & Mauritius & 614 & 0.01 \\
\hline
\end{tabular}

Source: Nigeria Insurance Digest 2011 P. 06. Culled from Swiss Re Economic Research \& Consulting. 
Al-Alak and Tarabieh (2011) states that market orientation is considered as a business culture that facilitates firms in achieving sustainable competitive advantage by creating superior customer value. A market orientation requires a clear understanding of both the present and future demand dynamics of target customers (Al-Alak and Tarabieh, 2011). This implies that since customers need change rapidly, market orientation is important for organisations to complete against one another in this competitive era, second ethically oriented insurance service firm.

Although, there have been many research publications of business ethics found in management literature in developed countries, there is little or no impact of business ethical relationship on insurance performance in Nigeria. What is the impact of business ethical relationship to insurance performance? This study is an attempt to conceptually evaluate insurance performance in Nigeria, and the possibility of applying business ethical relationship to insurance practice in Nigeria.

The following sections in this study review the importance and current insurance sperformance in theories applying to ethical business and the application of relationship to insurance of business ethical relationship to insurance operations in Nigeria. The final part of the paper presents discussions on the basis of the operational evaluations, managerial implications and recommendations.

\subsection{The Importance and Current Performance in Nigeria Insurance}

Insurance is risk transfer mechanism used primarily to hedge against an unforeseen contingency. By definition, insurance is a social scheme which provides financial compensation for the effects of a misfortune. The financial compensation is provided from the pool of accumulated contributions of all members participating in the scheme (Isimoya, 2007). Insurance is an institutional phenomenal and operates under a legal contract basis, as one of the many risk management tools. An insuring contract is therefore a legal agreement between the insurer (the insurance company) and the insured (policy holder), (Isimoya, 2007). An insurance contract is an arrangement in which one party, (the insurer/insurance company) promises to pay another party (the policy holder) a specified sum of money if something happens that causes loss (Diacon and Carter, 1984). The specified sum of money is paid in exchange of the small (token) amount of money paid periodically by the insured as a consideration, specified in the contract called the insurance policy.

Insurance plays a strategic role in the economy just as Irukwu (2003) stated that it is universally agreed that no modern economy can operate efficiently without the support of an organized, disciplined and viable insurance industry. Furthermore, Irukwu (2003) noted "As a key service industry in the financial services, insurance contributes a lot to the growth and stability of the national economy, both in the context of its primary role of risk bearing and as regards its secondary functions, in the nation's financial services industry, particularly in its roles in the mobilization of funds for investment in the national economy, and as promoter of savings culture 
and facilitator of the credit system". Nduna (2013) stated that African governments, after political independence, played a direct role in the insurance industry by setting up reinsurance and insurance companies to mobilize investable funds and stem the outflow of foreign currency from African countries. In addition, he stated that governments realized the importance of insurance in risks transfer, mobilization of savings to aid national development and general preservation of resources.

According to Irukwu (2003) the total investment of Nigerian Insurance Companies in government securities, in 1990, was a modest amount of N125m; while investment in stocks and shares amounted to $\mathrm{N} 261 \mathrm{~m}$. Progressively, the total investment to the national economy rose to N22bm by 1996 and N30bm by 1998. The table 1 below shows the growth of insurance companies' investment in the national economy from 2002 to 2011.

Table-2. Summary of Gross Premium Income and Total Investment $2002-2011$

\begin{tabular}{|c|c|c|c|c|c|c|}
\hline Year & $\begin{array}{l}\text { Gross } \\
000^{\prime}\end{array}$ & Premium & Income & $\%$ Increase & $\begin{array}{l}\text { Total } \\
\text { ooo }\end{array}$ & $\begin{array}{l}\% \\
\text { Increase/Decrease }\end{array}$ \\
\hline 2002 & & $44,503,828$ & & $34.4 \%$ & $79,855,127$ & $20.4 \%$ \\
\hline 2003 & & $55,940,566$ & & $25.7 \%$ & $123,192,373$ & $54.3 \%$ \\
\hline 2004 & & $69,410,804$ & & $24.1 \%$ & $154,119,166$ & $25.1 \%$ \\
\hline 2005 & & $763,254,817$ & & $100.0 \%$ & $184,235,177$ & $19.5 \%$ \\
\hline 2006 & & $82,289,108$ & & $7.8 \%$ & $257,859,283$ & $40.0 \%$ \\
\hline 2007 & & $100,619,511$ & & $22.3 \%$ & $379,914,481$ & $47.3 \%$ \\
\hline 2008 & & $150,259,567$ & & $49.33 \%$ & $427,571,377$ & $12.5 \%$ \\
\hline 2009 & & $179,940,788$ & & $19.09 \%$ & $327,481,989$ & $-23.4 \%$ \\
\hline 2010 & & $185,729,058$ & & $3.22 \%$ & 321,140325 & $-1.7 \%$ \\
\hline 2011 & & $217,748,008$ & & $17.24 \%$ & $288,497,860$ & $-10.16 \%$ \\
\hline
\end{tabular}

Source: Nigerian Insurance Digest 2011 Vol. 2 P. 58.

On the micro level, insurance serves as a solution to social problems. For instance, insurance provides financial compensation to victims of risks such as, transportation risks, industrial injuries, losses arising from the burglary, robbery, fire accidents, old age, illness, death of key employees, firm's liability, machinery breakdown, etc, who are participants to policy schemes. Oke (2012) stated that private insurers could give their contribution in solving the problem of social security system. They provide protection from the financial consequence of illness and injury, unemployment and retirement. Thus insurance products such as life, health and payment protection policies, can substitute for government social security programmes which are malfunctioning in Nigeria. In Nigeria, unlike the developed countries where citizens are protected to a certain extent, by social security programmes of the government, social security traditionally, is the responsibility of the community's organized age groups and the family. However, with the growth of middle class brought about by the rate of industrialization and urbanization, the social values is continually changing, therefore there is a weakening of the family bondage, which makes it necessary for every economic man to seek protection for his/her valuable possessions through accredited institutions like insurance, rather than the society. Nduna (2013) observed that 
urbanization that is taking place in Africa will create a large pool of middle class consumers who would require insurance cover.

The middle class in Nigeria is burgeoning. The middle class citizens are mostly educated urban dwellers, who are mostly professionals and formally employed. To this middle class, private insurers products are very important, due to their changed environment and demographic characteristics. Furthermore, new demographic situation which increase the percentage of the elderly, coupled with a falling birth/death rates and expectation of high level of health care and pensions, makes big pressure on social security system and could have negative effect on economic growth.

\subsection{Current Insurance Practice in Nigeria}

Insurance, with all its economic, strategic and social significance in an economy has not been performing outstandably well in Nigeria (see tables 1 and 2). In table 2, the percentage growth in the annual gross premium has not been progressively stable. The total investment growth by percentage also leaves much to be desired. In short, from 2009 to 2011 percentage investment contributions were in negative.

To buttress the above, Nduna (2013) stated that life insurance industry in Africa is relatively underdeveloped because most of the economically active people are employed in the informal sector where it is difficult to collect the premium as the majority of the people do not operate bank accounts.

In addition, he noted that African reinsurance market is still relatively small and less sophisticated. In 2011, the African reinsurance market represented in a mere 0. 8\% (\$6.4billion) of the world's share in direct premiums. Nduna did not fail to add, "The potential for the life assurance industry is largely untapped in the African continent and there is need for African insurers and reinsurers to invest in product research and development" (Nduna, 2013).

In table 1, Nigeria is ranked in comparison with ten top African countries in premium income, in 2011, in which Nigeria ranked the fourth position trailing behind Egypt, Morocco and South Africa. By land mass, population and insurable assets, Nigeria is first among all African countries. This is buttressed by Akingbola (2006) when he stated that though the Nigerian Insurance Industry boomed until the mid $-80 \mathrm{~s} \ldots$ the industry soon fell into turbulent times, particularly from the early 90 s as a result of the following: Undercapitalization of most insurance companies in the country; Poor product mix/pricing strategy; Gross inefficient service delivery channels; Low integrity of many insurance firms; Low insurance awareness among Nigerians; Poor labour practices; Poor information technology infrastructure; Poor regulatory mechanism, and Poor enforcement mechanism.

The Nigerian Insurance Industry before the 2006 recapitalization was triggered by the decline in the industry's goodwill. This was exemplified by shrinking market share leading to significant fall in gross premium income of all insurance companies in Nigeria (Ibrahim and Abubakar, 2011). 
On his part, Nduna (2013) noted that there is low insurance penetration in African countries due to many factors. For instance, he stated that there is general lack of trust of insurers by the general public, cultural and religious practices; no negative psychological effects of not having a policy amongst the majority of the population; low financial literacy amongst the populace; poor protection of consumers due to ineffective and ill-enforced legal frameworks; poor utilization of mobile phone technology, the internet and banassurance. The general public would loose confidence in the insurers where claims are not settled as planned, local insurance cover is not perceived as a good social security, and where there is little or no insurance educative progrommes to create insurance awareness. Other cases of low insurance include where members of the informal sector are not captured by insurance business and where there are no multiple insurance distribution channels.

Government in her wisdom, called for a panacea reform programme i.e. recapitalization of the insurance firms announced on $5^{\text {th }}$ September, 2005 as follows:

Table-3. Nigerian Insurance 2005 - 2006 Recapitalization

\begin{tabular}{lcccc}
\hline & Old Capital Base & New Capital Base & $\begin{array}{l}\text { Increase } \\
\text { Percentage }\end{array}$ & in \\
\hline Life Insurance Business & $\$ 150 \mathrm{~m}$ & $\$ 2 \mathrm{bm}$ & $1,233 \%$ \\
\hline General Insurance Business & $\$ 200 \mathrm{~m}$ & $\$ 3 \mathrm{bm}$ & $1,400 \%$ \\
\hline Reinsurance & $\$ 350 \mathrm{~m}$ & $\$ 10 \mathrm{bm}$ & $2,757 \%$ \\
\hline
\end{tabular}

The announcement was made by the honourable minister of finance Dr. (Mrs.) Ngozi Okonjo-Iweala. It was expected that by November 30, 2006, all insurance companies should have conclude their recapitalization i.e. merger and acquisition arrangements. The principal objective of the recapitalization of the insurance industry is to have the emergence of bigger and stronger players in the industry with enhanced capacity (Chukwulozie, 2007). Akingbola (2006) noted that by prescribing new capital requirements of $\$ 2$ billion, $\$ 3$ billion and $\$ 10$ billion for life, nonlife/general and reinsurance companies respectively, the new capital requirements are expected to put the insurance industry in a better position to add value to the Nigerian economy and grow beyond its present GDP contribution of less than $1 \%$. However, Ibrahim and Abubakar (2011) in a study titled: Recapitalization and Profitability of Quoted Insurance Companies in Nigeria, reported thus "The finding from the study revealed that recapitalization has not impacted significantly on the profitability of quoted insurance companies in Nigeria both before and after the 2006 recapitalization, even though there are some indications for improvement in absolute average profit figures during the post recapitalization, the increase in the share capital base of insurance companies in Nigeria, does not commensurate with the level of profitability achieved by the companies".

The challenges faced by African insurance industry are many and varied. Nduna (2013) stated that African insurance industry has limited underwriting capacity mainly due to weak capitalization. Big companies operating in Africa, especially mining companies, tend to insure 
their risks offshore because of limited capacity. The underwriting capacities of African insurance companies are often eroded in hard currency terms due to devaluation. Companies are often forced to write low valued risks and take small lines of business.

Insurance companies are also faced with the challenge of limited expertise and skills. (Nduna, 2013) opined that African insurance industry has not developed sufficient Research and Development capacity and has traditionally relied on the expertise from the advanced economies.

Consequently, the industry is always lagging behind in terms of product innovations. There is general reluctance by insurers to step out of the comfort zones (government and institutional accounts) and a taboo to explore the informal sector covers.

Nduna also stated that insurance in Africa is faced with the challenge of lack of proper infrastructure which often militates against the effective operation of insurance companies. Communication is often difficult due to bad roads and poor telecommunications. As if the above is not enough, the challenge of overtrading (rate-cutting) in some markets often stifles growth of the insurance industry in Africa, where companies compete on pricing to get some premium which covers expenses to the detriment of the interests of policy holders and shareholders (Nduna, 2013).

Insurance industry in Nigeria must start thinking the application of ethical decision making in her operations if she is to become profitable. As Omar (2007) reported that consumers' attitudes towards life assurance patronage in Nigeria is embedded in lack of trust and confidence in the insurance companies. This is coupled with lack of insurance awareness in Nigeria. Rok (2009) stated that the search for excellence and the search for ethics amount to the same thing, and both have to be connected to our concept of corporate strategy. We must learn to build corporate strategy on a foundation of ethical reasoning, rather than pretending that strategy and ethics are separate. Traditionally, insurance business thrives on trust since their service product is intangible and the buyer only experiences it at the occurrence of a specified event. High standards of organizational ethics can contribute to profitability by reducing the cost of business transactions, building a foundation of trust with stakeholders, contributing to an internal environment of successful teamwork and maintaining social capital that is part of an organization's market place image (McMurrian and Matulich, 2006).

Summarily, Ibrahim and Abubakar (2011) stated that even if the share capital of insurance is increased in multiples, the performance of the industry could still be limited by the attitudes of Nigerians. However, the application of business ethics which makes an organization to integrate core values such as honesty, trust, respect and fairness into its policies, practices and decision making, would cause an insurance company in Nigeria to endear itself to her stakeholders.

McMurrian and Matulich (2006) noted that there is a positive correlation between an organization's ethical behaviours and activities and the organization's bottom-line results. In addition, they said reputation for ethical business activities can be a major source of competitive advantage. 


\section{NORMATIVE ETHICAL THEORIES FOR BUSINESS DECISIONS}

The following are some of the notable normative ethical theories that individuals can apply in their decision makings and actions within business organisations. The focus here is on the distinction between deontological reasoning and utilitarian (teleological) reasoning because there is a tendency to exclude other possible ethical frames and theories based on the assumption that these two theories dominate ethical reasoning within organisations, (Pasternak, 2012)

\subsection{Utilitarian/Consequentialist Ethics}

Consequentialist ethics is the moral philosophy that is focused on maximizing human wellbeing. It is an ethical theory which is oriented towards outcomes or results. It is not based on promotion or acceptance of moral values put together nor does it strictly adhere to ethical principles.

According to Pasternak (2012), to utilitarian moral principle, an act is morally acceptable if it produces the greatest net benefit minus social costs. It takes into account all present and future benefits and harm that accrue or might accrue to anyone who is affected by the action including items that may be difficult to evaluate accurately (Pasternak, 2012). Utilitarian ethics does not assume all individuals should be treated equally, as it can endorse unequal treatment in order to maximize the society's welfare.

Employing this moral philosophy in business, we examine the consequences of our behaviours or actions. It asks; of what use is my decision? What good can I do? What harm does the behaviour create? Will the action make things better or worse? (Dobrin, 2009). When decisions are based on the answers to the above questions, it implies the consequentialism is forward looking i.e. what will be! The future consequencies of actions carried out today.

Utilitarian decision makers are required to estimate the effect of each alternative on all parties concerned and to select the optimum action that satisfies the greatest number Pasternak (2012).

\subsection{Ethical Egosism}

This is another teleological or consequential theory that measure morality based on consequences of actions. Ethical egosism focus exclusively on maximizing the welfare or good for the moral agent.

According to Pasternak (2012) the moral principle of ethical egosism suggests that an act is ethical when it promotes the individual's long term interest. In addition, Pasternak (2012) stated that it is possible for people to help others, follows the rules of society, and even grant gifts if they believe that those actions are in their best interest. The implication is that where such rules is not in agent's best interest, for instance, expectation for a firm to pay labour the prevailing industry's wage rate, the firm can act otherwise, which is in her best interest. 


\subsection{Deontological Ethical Theory}

This is another normative school of moral philosophy i.e. deontological ethics which focuses neither upon the persons' character or integrity (virtue school) nor upon what good outcomes the action will likely produce (consequentailist school), but upon the rule or moral principle. Thus, it is the intention behind an action rather than its consequences that make action good (Bowie, 2002). The ethical thing is the right thing and the right thing, is to do your duty in the light of the principles that reason has established (Dobrin, 2009).

Immanuel Kant, the German Philosopher is the propounder of this school of ethical philosophy. It is based on this ethical maxim: "So act that you use humanity whether it is your own person or in the person of any other, always at the same time as an end, never merely as a means”. People are ends per se. People have intrinsic value. Duties towards others inevitably lead to the notion that people have rights. It follows that people in business relationships shuold not be used, coerced or deceived, and that business organisations and practices should be arranged so that they contribute to the development of human rational and moral capacities (Bowie, 2002).

Kant distinguishes two kinds of imperatives, hypothetical and categorical imperatives. Hypothetical imperatives are conditional. For instance, if you want to achieve $\mathrm{Y}$, you should do $\mathrm{Z}$. This is instrumental in treating humans not as an end, but as a means to an end. Categorical imperative is unconditional and must be obeyed unconditionally. There are several formulas of categorical imperative, and three of them are called under the name of:

$>\quad$ Universal law of nature formula "act only according to the maxim whereby you can at the same time will that it should become a universal law".

Humanity formula "act in such a way that you treat humanity, whether in your own person or in the person of another, always at the same time as an end and never simply as a means".

$>\quad$ Kingdom ends formula "so act as if you were a member of an ideal kingdom of ends in which you were both subject and sovereign at the same time".

In the organizational arena, this means that the rules that govern an organization must be such that can be endorsed by every member in the organization (Pasternak, 2012). (Kingdom ends formula). Moreover, it implies that when a manager adopts the Karatian morality, he would see the organization as a moral community within every member of the organization stands in a moral relationship with other members (Humanity formula). The deontological ethics emphasis on universal morality which can be sum up in this phase 'treat others as you wish to be treated' (Universal law of nature formula). Deontological ethics rules out certain practices such as, theft, fraud, coercion, etc. that are found in business organizations today. That implies if deontological ethical maxims are applied in business circles, there will be no business ethical problems because the decisions are based on passing the test of categorical imperative i.e. is the principle based on good will? Does it treat people as ends in themselves? Can it be willed universally without contractions? Decisions will be immoral if otherwise. 
Ethics has an important place in all human endeavour, business inclusive. A business manager has responsibilities for his workers, customers, shareholders, suppliers, competitors, society, community, and the environment. In order to be ethically right in decision making, regarding the performance of the responsibilities, the business manager must base his decisions within a moral framework.

\subsection{Application of Business Ethics in Insurance Practice in Nigeria}

In order to appropriately define and understand the concept of business ethics, we need to first explore what the concepts of 'Business' and 'Ethics' stand for respectively.Carroll and Buchholtz (2006) Business "May be defined as the collection of private, commercially oriented (profit oriented) organizations ranging in size from one-person proprietorship (sole proprietor) (such as, Aqua Linda Restaurant, Gibson's Men's Wear, and Zin's Bagels) to corporate giants (such as, Johnson and Johnson, Bellsouth, Coca Cola, General Mills, and UPS). Between these extremes of course, are many medium-sized proprietorships, partnerships and corporations".

Ethics on the other hand, according to Oxford Learners Dictionary, means a "system of moral principles, rules and conduct". Ethics is a science of morals (Badi and Badi, 2006). Furthermore, they stated that the word ethics emerged from Latin "Ethicus" and in Greek "Ethicos - meaning character. Ethics is the study of proper and improper behaviour of moral duty and obligation. Further, they stated that for social researchers, ethics involves the responsibilities that researchers bear towards those who participate in research, i.e. those who are potential beneficiaries of research. The above implies that business ethics involves the responsibilities that business bears towards its stakeholders. These business responsibilities encompass a company's actions with regards not only to how it treats its employees and obeys the law, but also to the nature and quality of relationships it wishes to have with stakeholders, customers, business partners, suppliers, the community, the environment, the indigenous peoples, and even future generations.

Similarly, literature has management ethics, organizational ethics, marketing ethics, accounting ethics; auditing ethics all indicates what acceptable or unacceptable actions in the respective fields. Badi and Badi (2006) stated that, ethical issues in business can be divided into two types i.e. the overt (open and visible activities) and covert (hidden and invisible activities). 
Fig-1.

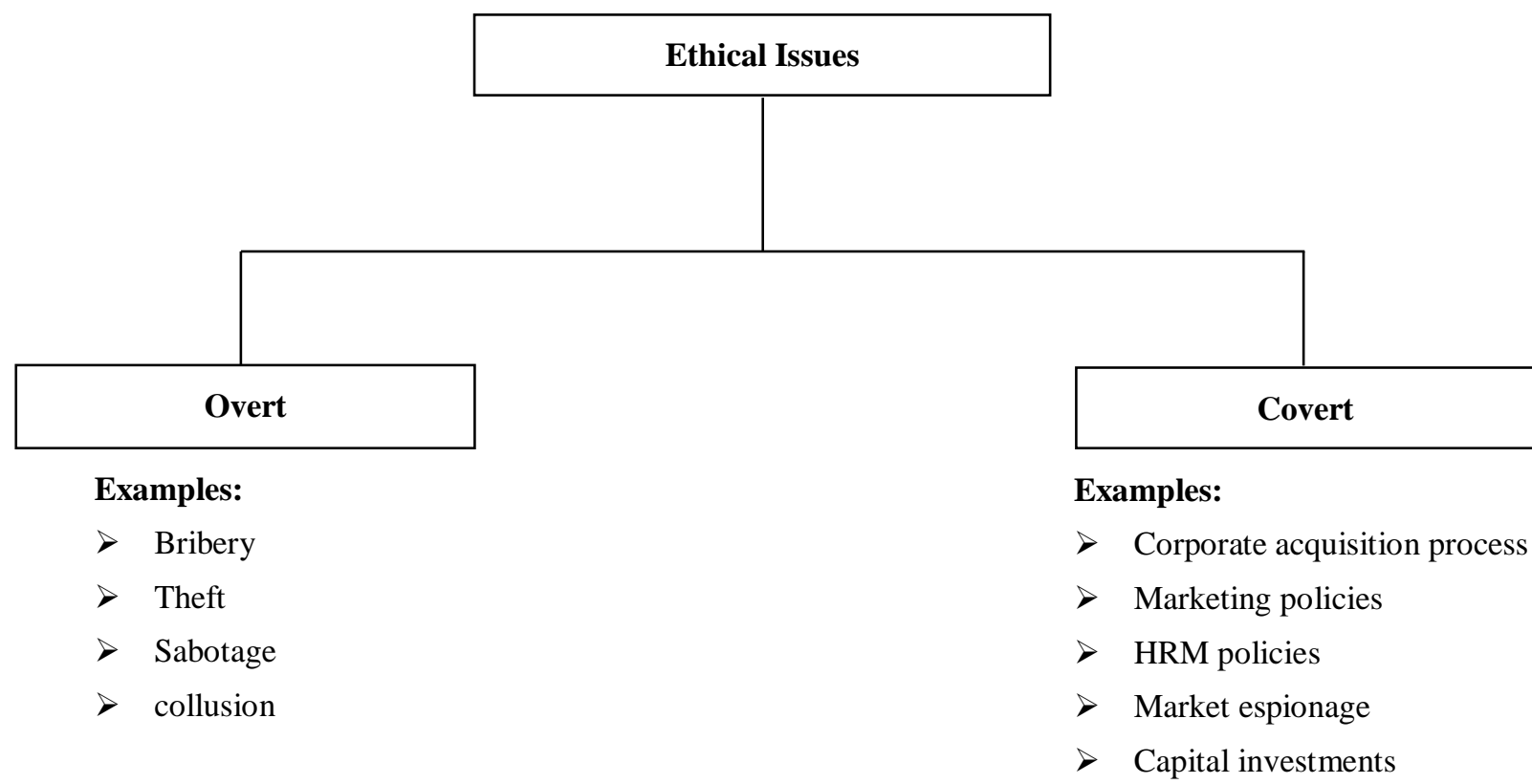

Source: Badi and Badi (2006) Business Ethics; Vrinda Publications (P) Ltd.

Carroll and Buchholtz (2006) highlighted the inventory of ethical issues in business, as given below.

Fig-2. Examples from Inventory of Ethical Issues in Business Employee-Employer

\section{Relations}

- $\quad$ - Work ethic - giving a full days work for a full day's pay.

- $\quad$ - Petty theft (i.e. supplies, telephone, photocopying, etc).

- $\quad$ - Cheating on expense accounts

- $\quad$ - Employee acceptance of gifts or favour from vendors.

- $\quad$ - Distortion of falsification of internal reports.

- $\quad$ - Cheating or overreaching on benefits (sick days, insurance, etc).

- $\quad$ - Sexual or racial discrimination in hiring, promotion or pay.

- $\quad$ - Sexual harassment.

- $\quad$ - Invasion of employee privacy.

- $\quad$ - Unsafe or unhealthy working conditions.

- $\quad$ - Discouragement of internal criticism re: unfair, illegal or improper Activities.

- Unfair demands on or expectations of paid staff.

- Inadequate recognition, appreciation or other psychic rewards to staff.

- Inappropriate blame shifting or credit taking to protect or 
advance personal careers.

- Unhealthy competition among employees about 'turf' assignments, budgets, etc.

\section{Company-Customer Relations}

- $\quad$ - Unfair product pricing.

- $\quad$ - Deceptive marketing/advertising.

- $\quad$ - Unsafe or unhealthy products.

- $\quad$ - Unfair and/ or legalistic handling of customer complaints.

- $\quad$ - $\quad$ Discourtesy or arrogance toward customers.

\section{Company-Shareholder Relations}

- $\quad$ - $\quad$ Excessive compensation for top management.

- $\quad$ - $\quad$ Self-protective management policies (golden parachutes, poison pills, green moil)

- $\quad$ - $\quad$ Mismanagement of corporate assets or opportunities.

- $\quad$ - Public reports and / or financial statements that distort actual performance.

\section{Company-Community/Public Interest}

- $\quad$ - Injury to the environment.

- $\quad$ - $\quad$ Undue influence on the political process through lobbying, PACs, etc.

- $\quad$ - $\quad$ Payoffs 'grease' or bribes in foreign countries.

- $\quad$ - $\quad$ Doing business in countries with inhumane or anti-American policies.

Souce: Carroll and Buchholtz (2006) culled from Josephson Institute of Ethics; Ethics: Easier said than done (Vol. 2, No. $1,1989)$.

Interest in business ethics accelerated dramatically during the 1980 s and 1990 s, both within major corporations and within academia (Kumar and Sharma, 2011), however it reached the highest tempo arising from corporate ethical scandals that plagued many notable corporate organizations in developed countries, early $21^{\text {st }}$ century, such as Enron, Adelphia, WorldCom, all in US; HIH Insurance limited in Australia. In Nigeria, the increasing trend of fraudulent, financial scandals, bankruptcies among commercial banks such as, Africbank Plc, Intercontinental Bank Plc, Oceanic Bank Plc, led to the sack and prosecution of the CEOs. These informed management scholars and media to continuously call for ethical leadership in corporate organizations. For instance, Jeffrey Skilling and Ray Williams both executive directors in Enron and HIH Insurance Ltd, respectively, were found guilty on common grounds i.e. 
$>$ Incompetence of the leaders and their failure to meet their duties under the Act.

$>$ Second was the use of creative accounting practices.

$>$ Third was the lack of ethics, honesty and integrity in the face of collapse (Armstrong and Francis, 2008).

Former HIH director, Rodney Adler was sentenced on April 14, 2005 after pleading guilty on $16^{\text {th }}$ February, 2005 to four criminal charges, which included.

$>$ Two counts of disseminating information knowing it was false.

$>$ One count of obtaining money by false or misleading statements.

$>$ One count of being intentionally dishonest and failing to discharge his duties as a director in good faith in the best interest of the company.

In Nigeria, the CEOs of Afribank Plc, Oceanic Bank Plc and Intercontinental Bank Plc, were all dismissed and prosecuted for financial misappropriations.

The above instances show that the leaders of the failed corporations were ethically bereft. Ponnu and Tennakoon (2009) observed that the common thread underlying these corporate scandals/commercial crimes is the failure of corporate leadership to demonstrate ethical leadership and its consequent negative impact on employee outcomes.

It is a necessity for insurance practitioners to show high level of social responsibility in every of their actions (Akinbola, 2010). As a vindication of the above, Irukwu (2009) noted that the professional disciplinary machinery must be strengthened to deal decisively with those who perpetuate such destructive and unprofessional practices such as the encouragement of fraudulent and grossly exaggerated claims and other unprofessional practices that damage the image and visibility of the insurance industry.

The above shows that the ethical issue present today in Nigeria insurance industry involves deception urge that confronts the individual i.e. to deceive or not. This dilemma is challenging because deceiving could lead to personal or organisational gains and it could even prevent harm sometimes (Pasternak, 2012). Furthermore, he also stated that deceiving could lead to undesired consequences as well. Deception can directly harm the deceived partly, and it could have future harmful consequences to a group of people and could even damage the agent or his/her organization if deception is discovered.

Consequently, (Irukwu, 2009) stated thus:

"There is clearly no future for an insurance industry whose functionaries indulge in or condone the type of destructive rate-cutting, premium purchase, and some other unprofessional practices that we have been witnessing in recent years. There is nothing professional in the conduct of the broker who insists on depleting the premium by insisting on being paid more than his legitimate brokerage in form of overriding commissions thereby endangering the insurer's capacity to pay legitimate claims and provide the appropriate reserves. There is nothing professional in the conduct of the Loss Adjuster, who insists on, and receives an inducement from the insured or claimant so that he can inflate the claim or recommend the payment of 
fraudulent claim or one that is not covered by the relevant policy. Unless these negative features, condoned by the insurance industry at present, are eliminated by the industry's professional leadership, our insurance professionals will find it difficult to cope with the changes of the new millennium"

However, Akinbola (2010) stated that before managers' behaviour can become ethical and reflect greater social responsibility, they must first perceive social responsibility to be important for organizational effectiveness. Nevertheless, McMurrian and Matulich (2006) in a research work titled "Building Customer Value and Profitability with Business Ethics" reported that from the business community, companies viewed to be ethical by companies' stakeholders (customers, employees, suppliers, and the public) do enjoy several competitive advantages. These advantages include higher level of efficiency in operations, higher level of commitment and loyalty, from employees, higher level of perceived product quality, higher level of customer loyalty and retention and better financial performance (Ferrell, 2004). McMurrian and Matulich also observed that business organizations' ethical behaviours and actions are the foundation of trust processes. Furthermore, ethics has a strong influence on customer perceptions of the level of process quality in doing business with an organization.

The above goes to prove that an ethically void insurance business may be successful in the short time period, but sustainability in the long run is dependent on the application of ethical norms and practices (Wise et al., 2010).

The sole aim earning of profit should not be only driving force in an insurance organization as ethical behaviour of its functionaries is very important. Just as Nirvathi et al. (2011) referred to profit not as the end of business but a score of its effectiveness. If management establishes fair, proper rules and regulations, including an equitable reward and punitive system for personel on the basis of their competence, ethical standards, discourage corruption and bribery, then ethics in business process can be improved (Wise et al., 2010).

There is an increasing expectation for insurance business to be more ethical and socially responsible in the way they discharge their duties. This is because by its nature, is exposed to criticism of ethics (Akinbola, 2010). Insurance purchase is basically on trust as the buyer would not experience it until the occurrence of a specified event. Therefore it is a necessity for insurance practitioners to show high level of social responsibility in every of their actions (Akinbola, 2010).

Although professional ethics has become more and more important today, world over, most insurance firms in Nigeria, do not own detailed code of ethics and practice documents that would guide practitioners at work. In short, every firm ought to have a code of ethics and conduct that would guide employees on what to do when faced with an ethical dilemma at work. Except for the industry's of code of ethics and practice published for the insurance industry, which is so remote that compliance by all members in the industry (the insurers, brokers, loss adjusters, agents, etc.) and the monitor for compliance by the supervisory authority, becomes relatively ineffective.

It is pertinent to point out that political independence and the spirit of nationalism in the early 60s, gave rise to expansion of insurance business in Nigeria. The proliferation of insurance companies was facilitated by weak conditions set by the 1961 insurance companies Act which 
stipulated a capital requirement of only N25,000 and provided for a weak supervisory outfit which was ill equipped to monitor and control the industry (Lijadu, 2009). No doubt, these mushroom companies are owned and managed by business men who lacked professional knowledge and knew next to nothing in insurance technically and ethically.

To buttress, Lijadu (2009) stated thus: 'The activities of the mushroom companies, within the context of weak control mechanism continued uncurbed in the seventies (70s) during which period widespread cases of malpractice caused a lot of damage to the image of the industry. Akinbola (2010) observed presently there is high level of market indiscipline going on in the way insurance business is been conducted in Nigeria. In the quest by the operators in the market to get their own share from the market, they engage in all sorts of unethical practices such as the rate cutting, hiding basic facts that the policy holders should know from them.

Kumar and Sharma (2011), noted that every business by its existence, irrespective of the demands and pressures upon it, is bound to be ethical for at least two reasons: One, because whatever the business does affects its stakeholders and two, because every juncture of action, has trajectories of ethical as well as unethical paths wherein the existence of business is justified by ethical alternative she responsibly chooses.

Ethics is very important in building relationship with clients and dealing with them. Ethics in business helps to establish an entity's reliability and reputation with its clients (Akinbola, 2010). It is a norm that nobody will want to be in business with a person or company known to be fraudulent (Akinbola, 2010).

Increasing international business affairs call for moral absolutes to be formed and used more apparently. This movement calls for ethical universalism and proactive Corporate Social Responsibility (CSR) which could provide a platform for a universal ethical standard that could become the norm of society and businesses in India and internationally (Nirvathi et al., 2011). No doubt, insurance industry in Nigeria has an urgent need for repositioning as well as re-equipping the institutions and practitioners for a more efficient, effective and competitive industry. Akinbola (2010) stated that Nigeria contributed only 0.7\% to GDP while South Africa contributed 12\%. UK contributes further, the scholar noted that while insurance companies stand as financial backbone in developed countries, the reverse is the case in Nigeria, despite its large population. Adewunmi (2009) noted that if insurance firms and practitioners can give desirable attention to their reputation, the benefits they provide to their clients, operate more efficiently to enable them bring down their premium rate and enhance personality and capability of their agents and brokers, we can expect increased patronage of this sub sector in the near future. Irukwu (2009) stated that, in response to sacred insurance law principle of uberrima fidei; or the doctrine of the utmost good faith, he is obliged to confess that whilst the majority of insurance professionals are conducting their professional activities with absolute commitment, we do have a few practitioners, in all sections of the insurance industry, who have very little regard for professionalism and ethics in the conduct of their business activities. Furthermore, he advised that the professional disciplinary machinery must be strengthened to deal decisively with those who perpetuate such destructive 
and unprofessional practices as rate-cutting premium purchase, other forms of market indiscipline such as the encouragement of fraudulent and grossly exaggerated claims and other unprofessional practices that damage the image and visibility of insurance industry.

Onaolapo (2005) stated that unprofessional practices still abound especially in the areas of business acquisition as prospective insured and intermediaries are always inclined to exploit the cut-throat competition in the industry. In addition, he noted that many underwriters are prepared to submit to pressures for fear of loosing business. Rate-cutting and offer of illegal inducement have eroded the profitability of the industry.

\section{CONCLUSION AND RECOMMENDATIONS}

The purpose of this article has been to conceptually discuss the concepts of business ethics, its applicability and benefits to insurance industry in Nigeria.

It has been observed that insurance practice in Nigeria is devoid of ethical orientation, as many firms do not have code of ethics that govern their operations. Second, the widespread unethical practices like rate cutting, premium loading, overriding commission, premium purchase, under-indemnity, (Soares, 2004), (Irukwu, 2009) also bear testimony to lack of ethical behaviour in Nigeria insurance business practice.

Recognizing the fact the ethical business relationship with stakeholders builds customer value and profitability through several competitive advantages such as customer loyalty and retention, product quality, efficiency in operations, insurance in Nigeria would perform outstandingly better, if she is ethically oriented. Although there are still some companies who believe that unethical business practices will not be discovered, or even when discovered it will not harm their business standing, there are still good reasons while service organizations should be concerned about their ethical reputations. First, business relations and operations affect its stakeholders. In service organization any company that is not trusted by its employees, customers, suppliers and other associates, would gradually and steadily decline in both growth and financial performance in the long term. Second, every business action has a trajectory effect ethical or unethical. Continual unethical practices could lead to government intervention and regulations which will be more problematic than self policing in the first place (McMurrian and Matulich, 2006).

Insurance as a strategic business activity in Nigerian developing economy, much bottlenecks have been identified as responsible for its poor performance and growth. Some identified problems affecting the business as revealed by past researchers, include ethical issue, poor premium collection; solvency problem/low liquidity, lack of standards, absence of government, poor management, low level of information technology, lack of integrity/trust, attitudes of Nigerians as towards insurance services, lack of innovation, (Akinbola, 2010).

Sequel to the above, we put up the following recommendations: 
1. Insurance companies need developed and adapt their products to local demands. For instance, the large informal sector would be best served with micro insurance cover. This would help improve insurance penetration.

2. Insurance potential buyers need to be educated on good risk management practices and benefits of insurance policies.

3. Insurance regulation should have the objective of protecting the insurance consumer, investors and on the standardization of the conduct in insurance provision/delivery of service.

4. Banassurance is one of the potent insurance distributive channels in the emerging economies of the world. Insurance in Nigeria should synergize with the commercial banks to reap the benefits of banassurance.

5. Ethical business practices and relationship should be encouraged in all insurance business organizations. This would be the responsibility of ethical leaders who would be appointed to lead the organizations. As an ethical leader, he would be a moral person and a moral manager. As a moral person, he would be honest, fair and equitable in all his dealings with internal and external stakeholders of his firm. Second, he would also manifest as a moral manager, i.e. one who heralds ethical conduct, encourages followers to be ethical through rewards and discourages unethical behaviour through reprimand and punishment.

6. Every insurance underwriting firm and the intermediaries like the insurance brokers and loss adjusters should be encouraged to develop a code of ethics and conduct, to guide their employees in decision making when faced with moral issues in operations.

7. Insurance customers and clients should be respectfully and properly treated. If employees would ethically attend to the customers in services offered, the diminishing mutual trust between the insurer and the insured will be boosted.

8. Only technically knowledgeable and morally upright leaders should be appointed to insurance corporate boards. Political interference and undue pressure from business owners and board members should be discouraged.

9. The college of insurance and the Chartered Insurance Institute of Nigeria, as the educational arms of the industry, should encourage moral education. Morals and business ethics should be in their syllabi while workshops and conferences on business ethics should be organized regularly.

10. Insurance leaders under the aegis of Nigerian Insurers Association should set up a Special Investigation Commission (SIC) charged with the formation of coalition against fraud and unethical practices in Nigerian Insurance Industry. SIC investigations and recommendations should be mandatory.

\section{Funding: This study received no specific financial support.}

Competing Interests: The author declares that there are no conflicts of interests regarding the publication of this paper. 


\section{REFERENCES}

Adewunmi, W., 2009. Repositioning the insurance industry: Insurance practice practitioners and ethics. Insurance professionalism in Nigeria. Golden Anniversary of the Chartered Insurance Institute of Nigeria. P: 134-163.

Akinbola, O.E., 2010. Ethical issue: A problem in Nigeria insurance companies. A Masters Thesis in MBA Submitted to School of Management Blekinge Institute of Technology Sweden.

Akingbola, E.B.O., 2006. Maximizing investment opportunities in insurance under the current reforms. In Chiejina E. O. (Eds) Issues in recapitalization and consolidation in the Nigeria Insurance Industry. pp: 1-12.

Al-Alak, B.S. and S.A. Tarabieh, 2011. Gaining competitive advantage and organisational performance through customer orientation, innovation differentiation and market differentiation. International Journal of Economics and Management Sciences, 1(5): 80-91.

Armstrong, A. and R. Francis, 2008. Loss of integrity: The true failure of the corporate sector. Journal of Business Systems, Governance and Ethics, 3(3):1-13.

Azmi, R.A., 2006. Business ethics as competitive advantage for companies in the globalization Era. Available from http://ssm.com/abstract $=1010073$.

Badi, R.V. and N.V. Badi, 2006. Business ethics. Vrinda Publications (P) Ltd. B-5 Aashish Complex, Mayur Vihar Phase-l, Delhi - 110091.

Bowie, N.E., 2002. A kantian approach to business ethics. In Frederick, R.E. A companion to business ethics. UK: Blackwell.

Carroll, A.B. and A.K. Buchholtz, 2006. Business and society. Ethics and stakeholder management. 6th Edn., South-Western. Thoruson. Ohio 45040.

Chukwulozie, E., 2007. Big is beautiful African business special report. Available form www.africasia.com/uploads/ab-nigeria_insurance_0407.pdf.

Diacon, S.R. and R.L. Carter, 1984. Success in insurance, John Murray Publishers Ltd. 50 Albermarle Street, London WIX 4BD.

Dobrin, A., 2009. Business ethics. The right way to riches. Available from www.arthurdobrin.files.wordpress.com/2008/08/business-ethics.pdf.

Ferrell, O.C., 2004. Business ethics and customer satisfaction. Academy of Management Executive, 18(2): 126-129.

Ibrahim, H. and S. Abubakar, 2011. Recapitalization and profitability of quoted cnsurance companies in Nigeria. Available from www.businessafricaevents.com/docs/pdf/transformation.

Insurance Professionalism in Nigeria, 2011. Golden jubilee anniversaryof the chartered insurance institute of Nigeria. P: 47-65.

Irukwu, J.O., 2003. The evolution of insurance in Nigeria. The compendium of insurance business in Nigeria. Published by The Financial Service Group LCCI + CBS Consulting. pp: 23-31.

Irukwu, J.O., 2009. Professionalism in the Nigerian insurance industry: The Challenge For This Millennium. Isimoya, O.A., 2007. Fundamentals of insurance (Revised Edition). Concept Publications Ltd. P. O. Box 2516. Mushin Lagos. 
Kumar, S. and N.P. Sharma, 2011. Concept of business ethics in India: A study. International Journal of Contemporary Practices, $2(2)$.

Lijadu, Y., 2009. Historical perspective of Nigeria's insurance industry. In insurance professionalism in Nigeria. A Collection of Essays in Commemoration of the Golden Jubilee Anniversary of the Chartered Insurance Institute of Nigeria. pp: 1-14.

McMurrian and Matulich, 2006. Building customer value and profitability with business ethics. Journal of Business and Economics, 4(1 1): 11-18.

Nduna, A.J., 2013. Low insurance penetration in emerging economics and way forward - The African experience. In Zimbre Holdings Limited at the 17th Insurance Congress of Developing Countries (ICDC) Colombo Srilanka. pp: 1-14.

Nirvathi, S., A. Quazi and A. Saleh, 2011. Developing ethical and CSR standards in Indian corporate sector. A Conceptual Analysis. Available from www.anzmac.org/...Nivathi\%20Sarangapani\%20\%20papaer\%20629.pd.

Obaremi, N., 2007. Insurance in Nigeria. An African business special Report.

www.africasia.com/uploads/ab-nigeria_insurance_0407.pdf.

Oke, M.O., 2012. Insurance sector development and economic growths in Nigeria. African Journal of Business Management, 6(23): 7016-7023.

Omar, O.E., 2007. The retailing of life insurance in Nigeria: An assessment of consumers attitude. Journal of Retail Marketing Management Research, 1(1): 41-47.

Onaolapo, W., 2005. Insurance: How professional. A Workshop Paper Delivered in Chartered Insurance Institute of Nigeria Port Harcourt.

Pasternak, S., 2012. The role of ethical theories in ethical reasoning and behaviour within organisations. Unpublished Research Proposal Submitted to the Faculty of Management, Tel Aviv University. Available from www.ti-isreal.org/.../dbs-Atachedfiles/sigalitPasternak.pdf.

Ponnu, C.H. and G. Tennakoon, 2009. The association between ethical leadership and employee outcomesThe Malaysian case. EJBO Electronic Journal of Business Ethics and Organisation Studies, $14(1): 21-32$.

Rok, B., 2009. People and skills ethical context of the participative leadership model: Taking people into account. Corporate Governance, 9(4): 461-472.

Soares, P.M.G., 2004. Developing public trust in insurance - a critical appraisal. Journal of Chartered Insurance Institute of Nigeria, 5(13): 15-24.

Wise, V., M.M. Ali and T.D. Wise, 2010. Ethical conduct in business: A case study analysis using Bangladesh experiences. Problems and Perspectives in Management, 8(4): 184-192.

Views and opinions expressed in this article are the views and opinions of the author(s), International Journal of Management and Sustainability shall not be responsible or answerable for any loss, damage or liability etc. caused in relation to/arising out of the use of the content. 